\title{
OBITUARY \\ Dennis Newton: born 9 July 1940, died 10 February 2017
}

Spinal Cord (2017) 55, 628; doi:10.1038/sc.2017.50

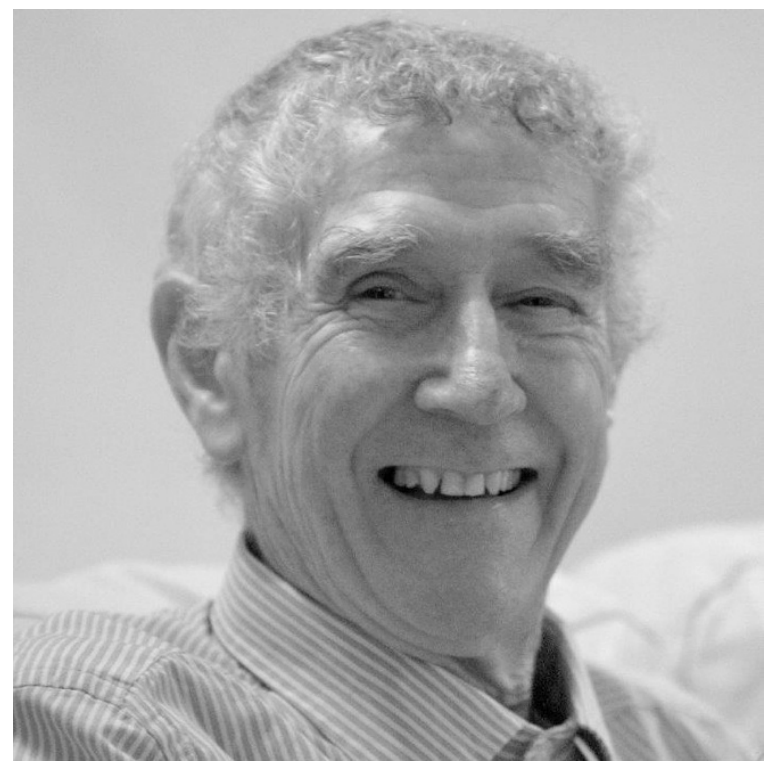

Dennis Andrew Newton was born in Johannesburg in 1940. After his degree in theology at Rhodes University, Grahamstown, he became a Christian minister. While working in a church on the edge of the Kruger National Park, he often accompanied a doctor friend on home visits. These experiences cultivated in him a keen interest in medicine. After 10 years in the ministry, he decided to study medicine and became an orthopaedic surgeon with a special interest in spinal surgery.

Between 1988 and 2000, Dennis made himself immediately available at Conradie Hospital in Cape Town to relocate, as an emergency, cervical spines dislocated during rugby matches. The second author of this obituary recalls a meal with Dennis, when during the meal Dennis received a telephone call and left immediately to carry out an emergency cervical spinal reduction.

In a series of 113 rugby injured patients, Dennis showed that, if the dislocated spine was relocated within $4 \mathrm{~h}$ of injury, $64 \%$ of those who were initially completely tetraplegic made a full recovery. None relocated after this time recovered fully, and only one recovered partially to a useful degree. With the help of the Rugby Injured Players Foundation at Twickenham, his work was published in 2011 in the British Journal of Bone and Joint Surgery. This was a significant advance in acute spinal cord injury management, particularly applicable in places where urgent surgery is not available.

In a landmark legal case in South Africa in 2015, the Constitutional Court of South Africa, which is the highest court in that country, decided that Charles Oppelt, who was rendered completely tetraplegic in a rugby match should have been relocated within $4 \mathrm{~h}$ of his injury. Dennis was delighted that, following this judgement, the Minister for Health went to the hospital concerned and instructed, in uncompromising terms, that all such patients must be relocated within $4 \mathrm{~h}$ of injury. This action undoubtedly saved some rugby injured players from lifelong paralysis.

Dennis was greatly admired and respected by his patients, many of whom became lifelong friends. He recalled one such patient in Conradie, a local mafia boss, who expressed his gratitude by arranging for his own security team to put a stop to the regular pilfering of the copper pipes from the spinal unit.

His colleagues at Conradie held him in the highest regard. His junior colleagues recall that he was always happy except on one or two rare occasions when, for very good reason, he would become red in the face and they would run for cover! They looked on him as a father to all in the hospital.

Morné du Plessis, the Springboks' most successful Captain and Manager of the 1995 Springboks team that won the Rugby World Cup and Chairman of the Chris Burger Players fund said: "Dennis will always be remembered fondly and with great respect by all at the Players' Fund, for the incredible way that he handled our rugby players who had sustained spinal cord injuries on the field. He was a great source of expertise to us and always made himself available to give advice and encouragement, not only to our brave young men but also to ourselves as a charitable organisation".

At the age of 62, Dennis moved to England where he worked as a consultant orthopaedic spinal surgeon. From 2006 until his retirement in 2014, he served in this role at the National Spinal Injuries Centre in Stoke Mandeville, where he was liked and admired by his patients and the staff.

Dennis was a member of the International Spinal Cord Society and a practical supporter of its aim to improve the care of those with spinal cord injury.

Dennis was a strong family man who celebrated his fiftieth wedding anniversary in 2016. He died on 10 February 2017. He is survived by his wife Joleen, their three children and eight grandchildren. One daughter works as a Doctor in Emergency Medicine in England.

Dennis will be remembered as a compassionate, people-focussed person. He was a humble man who cared deeply for others. This, and the early reduction of low velocity cervical cord injuries, form an enduring legacy.

Brian Gardner ${ }^{1}$ and Douglas Brown ${ }^{2,3}$ ${ }^{1}$ Spinal Cord Injury, National Spinal Injuries Centre, Stoke Mandeville Hospital, Aylesbury, UK; ${ }^{2}$ Victorian Spinal Cord Service, Royal Talbot Rehabilitation Centre, Austin Health,

Kew, VIC, Australia and ${ }^{3}$ Spinal Research Institute, Royal Talbot Rehabilitation Centre, Austin Health, Kew, VIC, Australia E-mail: office@bgardner.co.uk 